Article

\title{
Preclinical Pharmacokinetics of C118P, a Novel Prodrug of Microtubules Inhibitor and Its Metabolite C118 in Mice, Rats, and Dogs
}

\author{
Cang Zhang ${ }^{1,2,+}$, Xiaolan Zhang ${ }^{3,+}{ }^{,}$Guangji Wang ${ }^{3}$, Ying Peng ${ }^{3}$, Xueyuan Zhang ${ }^{3}$, Hui Wu ${ }^{3}$, \\ Boyang $\mathrm{Yu}^{1, *}$ and Jianguo Sun ${ }^{3, *}$ \\ 1 School of Traditional Chinese Pharmacy, China Pharmaceutical University, Nanjing 211198, China; \\ zhangcang@sanhome.com \\ 2 Nanjing Sanhome Pharmaceutical Co. Ltd., Nanjing 211135, China \\ 3 Key Lab of Drug Metabolism and Pharmacokinetics, State Key Laboratory of Natural Medicines, \\ China Pharmaceutical University, Nanjing 210009, China; zhangxiaolan735@163.com (X.Z.); \\ guangjiwang@hotmail.com (G.W.); pengy2014@126.com (Y.P.); xueyuanzh@yeah.net (X.Z.); \\ wuhui0922@hotmail.com (H.W.) \\ * Correspondence: boyangyucpu@163.com (B.Y.); jgsun@cpu.edu.cn (J.S.); Tel.:+86-25-8618-5287 (B.Y.); \\ +86-25-8327-1176 (J.S.) \\ + These authors contributed equally to this work.
}

Received: 4 October 2018; Accepted: 1 November 2018; Published: 5 November 2018

check for updates

\begin{abstract}
C118P, a phosphate prodrug of $\mathrm{C} 118$, which is a novel microtubule protein inhibitor, is currently under Phase I clinical development in China for treating ovarian cancer and lung cancer. The preclinical pharmacokinetics of prodrug C118P and its metabolite C118 were extensively characterized in vivo in mice, rats, and dogs and in vitro to support the further development of C118P. The preclinical tissue distribution and excretion were investigated in rats. Plasma protein binding in mice, rat, and human, and hepatic microsomal metabolic stability in mice, rat, dog, monkey, and human, were also evaluated. The $\left(\mathrm{AUC}_{0 \text {-inf }}\right)$ and $\mathrm{C}_{30 \mathrm{~s}}$ of $\mathrm{C} 118 \mathrm{P}$ at $50 \mathrm{mg} / \mathrm{kg}$ in rats and $6 \mathrm{mg} / \mathrm{kg}$ in dogs, and the $\mathrm{C}_{2 \mathrm{~min}}$ of $\mathrm{C} 118$ at $6 \mathrm{mg} / \mathrm{kg}$ in dogs increased less than the dosage increase, suggested nonlinear pharmacokinetic occurred at high dose. As a prodrug, $\mathrm{C} 118 \mathrm{P}$ can be quickly hydrolyzed into C118 after an intravenous administration. The unbound C118 in plasma is slightly higher than C118P. $\mathrm{C} 118 \mathrm{P}$ can hardly penetrate the tissue, while $\mathrm{C} 118$ can distribute widely into tissues. In tumor-bearing nude mice, the concentration of C118 is high in lung, ovary, and tumor, with an extended half-life in tumor. $\mathrm{C} 118 \mathrm{P}$ is a promising candidate prodrug for further clinical development.
\end{abstract}

Keywords: C118P; microtubules inhibitor; prodrug; pharmacokinetics; simplified tandem two-compartmental model

\section{Introduction}

Cancer is the most important cause of death in China and has been a major public health problem, with increasing incidence and mortality. An estimated 4,292,000 new cancer cases and 2,814,000 cancer deaths occurred in China in 2015, with lung cancer being the most common incident cancer and the leading cause of cancer death [1]. In 1971, Folkman proposed the important role of angiogenesis in tumor growth and metastasis [2]. Tumor growth, invasion, metastasis and prognosis are related to tumor angiogenesis [3-7]. There are two types of therapeutic drugs for tumor blood vessels: anti-angiogenesis (VTA) agents and VDAs (vascular disrupting agents) mainly belonging to microtubule protein inhibitors which selectively destroy the tumor vascular system $[8,9]$. Acute administration of VDAs yields an immediate vascular collapse in contrast to angiogenesis 
inhibitors, which typically require multiple drug administration. VDAs can also increase vascular permeability, interstitial pressure causing plasma leakage, and reduce blood vessel diameter, blood flow and, therefore, vascular shutdown [10].

Combretastain A4 (CA4, Figure 1A), isolated from the African bush willow Combretum caffrum, is the most potent naturally occurring combretastatins in regards to tubulin binding ability. Its prodrug CA4 phosphate (CA4P, Figure 1B) can inhibit tumor blood flow at far low concentration than the clinical maximal tolerated dose. CA4P can block new vessel formation and subsequently decrease cell migration and metastasis [10]. CA4P is mainly applied to thyroid cancer, ovarian cancer, non-small cell lung cancer and is currently in phase II study [11,12].

C118P (Figure 1C), an analog of CA4P, was developed by Nanjing Sanhome Pharmaceutical Co. Ltd. (Nanjing, China) as a phosphate prodrug of C118 (Figure 1D), and is currently under Phase I clinical trial in China for the treatment of solid tumors. The preliminary study showed that C118P displayed good inhibitory activities against ovarian cancer and lung cancer. Furthermore, the structure design of $\mathrm{C} 118$ avoids the potential generation of quinone metabolites in vivo. The efficacy and safety after structure modification were supposed to be improved.

A<smiles>COc1ccc(/C=C\c2cc(OC)c(OC)c(OC)c2)cc1O</smiles>

$\mathrm{C}_{18} \mathrm{H}_{20} \mathrm{O}_{5}$

Exact Mass: 316.1311

CA4

C<smiles>COc1cc(OC)cc(-c2nc[nH]c2-c2ccc(OC)c(OP(=O)(O)O[Na])c2)c1</smiles>

$\mathrm{C} 118 \mathrm{P}$<smiles>COc1ccc(/C=C\c2cc(OC)c(OC)c(OC)c2)cc1OP(=O)(O)O[Na]</smiles>

CA4P

D

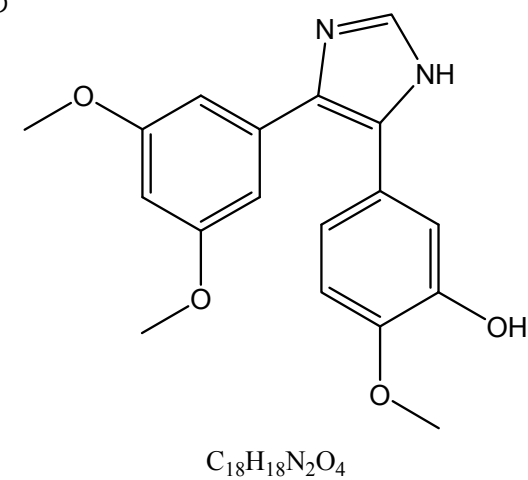
Exact Mass: 326.1267

$\mathrm{C} 118$

Figure 1. Chemical structure of CA4 (A), CA4P (B), C118P (C) and C118 (D).

In this study, the preclinical plasma pharmacokinetic (PK) profiles of C118P and C118 in mice, rats and dogs, the preclinical tissue distribution and excretion in mice and rats, were investigated after a single intravenous administration. The in vitro PK profiles of $\mathrm{C} 118 \mathrm{P}$ and $\mathrm{C} 118$, including plasma protein binding and hepatic microsomal metabolic stability in different species, were also evaluated. 


\section{Results and Discussion}

\subsection{Plasma Protein Binding and Whole Blood/Plasma Ratio}

Both C118P and C118 were stable in the plasma with EDTA as anticoagulant. The non-specific binding to the ultrafilter membrane was negligible. The extent of plasma protein binding was reported as a fraction unbound ( $\mathrm{fu}, \%$ ) value which was calculated using the formula $\mathrm{fu}=\mathrm{PF} / \mathrm{TC} \times 100 \%$, where $\mathrm{TC}$ is test compound ( $\mathrm{C} 118 \mathrm{P}$ or $\mathrm{C} 118)$ concentration in sample before ultrafiltration, and $\mathrm{PF}$ is the test compound concentration in the ultrafiltrate (Table 1).

Table 1. The fu values of $\mathrm{C} 118 \mathrm{P}$ or $\mathrm{C} 118$ in rat, dog, and human plasma ( $\%$, mean $\pm \mathrm{SD})$.

\begin{tabular}{ccccc}
\hline \multirow{2}{*}{ Species } & \multicolumn{4}{c}{ Concentration of C118P (ng/mL) } \\
\cline { 2 - 5 } & $\mathbf{4 0 0}$ & $\mathbf{4 0 0 0}$ & $\mathbf{4 0 , 0 0 0}$ & $\mathbf{4 0 0 , 0 0 0}$ \\
\hline Rat & $3.2 \pm 0.1$ & $2.9 \pm 0.1$ & $2.4 \pm 0.1$ & $12.2 \pm 0.6$ \\
Dog & $1.9 \pm 0.1$ & $2.1 \pm 0.1$ & $2.7 \pm 0.2$ & $8.6 \pm 0.3$ \\
Human & $2.2 \pm 0.1$ & $2.7 \pm 0.0$ & $2.2 \pm 0.1$ & $5.7 \pm 0.4$ \\
\hline \multirow{3}{*}{ Species } & \multicolumn{4}{c}{ Concentration of C118 (ng/mL) } \\
\cline { 2 - 5 } & $\mathbf{2 0} *$ & $\mathbf{2 0 0}$ & $\mathbf{2 0 0 0}$ & $\mathbf{2 0 , 0 0 0}$ \\
\hline Rat & 0 & $7.7 \pm 0.8$ & $6.5 \pm 0.3$ & $5.5 \pm 0.1$ \\
Dog & 0 & $5.8 \pm 0.2$ & $6.2 \pm 0.4$ & $5.4 \pm 0.4$ \\
Human & 0 & $2.8 \pm 0.2$ & $4.7 \pm 0.2$ & $3.8 \pm 0.2$ \\
\hline
\end{tabular}

* The concentrations of C118 in the upper layer were below the lower limit of quantification (LLOQ).

The whole blood/plasma ratio in rat was 0.80 for C118P and 1.05 for C118, respectively. C118P and C118 can distribute into blood cell since the ratio is significantly higher than 0.55 .

\subsection{In Vitro Metabolism by Liver Microsomes}

C118P was quite stable in liver microsomes of human, mice, rat, and monkey and was not stable in dog microsomes (Figure S1). The in vitro liver microsomal metabolism of C118 in various species, as measured by the disappearance of C118, is summarized in Table 2. The CLint, in vitro of $\mathrm{C} 118$, was $44.7,67.0,9.9,318.6$, and $58.2 \mu \mathrm{L} \cdot \mathrm{min}^{-1} \cdot \mathrm{mg}^{-1}$ protein in mice, rat, dog, monkey, and human liver microsomes, respectively. The rate of C118 metabolism in microsomes followed the order monkey $>$ rat $>$ human $>$ mice $>$ dog. Since the C118 is mainly metabolized in liver and excreted in bile, $\mathrm{CL}_{\mathrm{H}}$ is supposed to be near CL. Compared with the observed CL, mouse and rat were best predicted with the accuracy within 2 folds. The prediction of dog is less accurate with accuracy larger than three-fold (Table 2).

Table 2. Metabolic stability of C118 in liver microsomes of different species.

\begin{tabular}{|c|c|c|c|c|c|}
\hline Species & $t_{1 / 2}(\min )$ & $\begin{array}{c}\mathrm{CL}_{\text {int, in vitro }} \\
\left(\mu \mathrm{L} \cdot \mathrm{min}^{-1} \cdot \mathrm{mg}^{-1} \text { Protein }\right)\end{array}$ & $\stackrel{\mathrm{CL}_{\text {int }}}{\left(\mathrm{mL} \cdot \mathrm{min}^{-1} \cdot \mathrm{kg}^{-1}\right)}$ & $\begin{array}{l}\text { Extrapolated } \mathrm{CL}_{\mathrm{H}} \\
\left(\mathrm{mL} \cdot \mathrm{min}^{-1} \cdot \mathrm{kg}^{-1}\right)\end{array}$ & $\begin{array}{c}\text { Observed CL } \\
\left(\mathrm{mL} \cdot \mathrm{min}^{-1} \cdot \mathrm{kg}^{-1}\right)\end{array}$ \\
\hline Mice & 15.5 & 44.7 & 115.3 & 49.3 & 88.8 \\
\hline Rat & 10.3 & 67.0 & 115.3 & 43.6 & 62.9 \\
\hline Dog & 70.1 & 9.9 & 18.9 & 12.8 & 54.0 \\
\hline Monkey & 2.2 & 318.6 & 252.8 & 37.5 & / \\
\hline Human & 11.9 & 58.2 & 47.9 & 14.1 & / \\
\hline
\end{tabular}




\subsection{PK in Mice, Rats, and Dogs}

Both C118P and C118 were detectable in mice, rat, and dog plasma after i.v. injection of C118P. The plasma-concentration versus time profiles of C118P and C118 are shown in Figure 2. The PK parameters of $\mathrm{C} 118 \mathrm{P}$ and $\mathrm{C} 118$ calculated from their concentrations in mice, rat, and dog plasma are presented in Table 3. The exposure ( $\mathrm{AUC}_{0 \text {-inf }}$ ) and $\mathrm{C} 30 \mathrm{~s}$ of $\mathrm{C} 118 \mathrm{P}$ increased proportionally to the dose in the range of $5-20 \mathrm{mg} / \mathrm{kg}$ in rats and $1-3 \mathrm{mg} / \mathrm{kg}$ in dogs. The (AUC $\mathrm{A}_{\text {-inf }}$ ) and C30s of C118 increased proportionally to the dose in the range of $5-50 \mathrm{mg} / \mathrm{kg}$ in rats and $1-3 \mathrm{mg} / \mathrm{kg}$ in dogs. The $\left(\mathrm{AUC}_{0 \text {-inf }}\right)$ and $\mathrm{C}_{30 \mathrm{~s}}$ of $\mathrm{C} 118 \mathrm{P}$ at $50 \mathrm{mg} / \mathrm{kg}$ in rats and $6 \mathrm{mg} / \mathrm{kg}$ in dogs increased less than the dosage increase. The $\mathrm{C}_{2 \mathrm{~min}}$ of $\mathrm{C} 118$ at $6 \mathrm{mg} / \mathrm{kg}$ in dogs increased less than the dosage increase, which suggested nonlinear pharmacokinetics occurred at high dose.
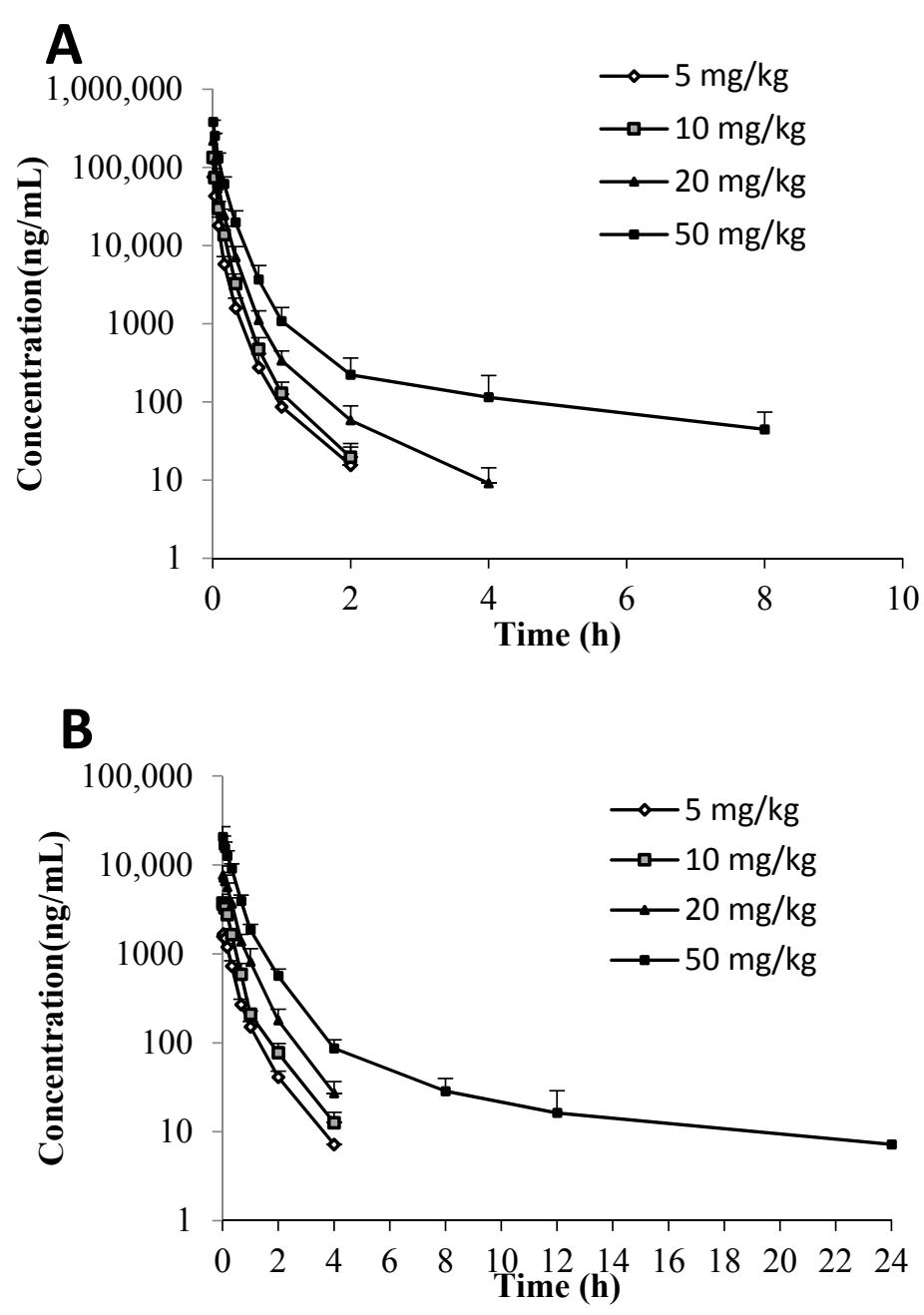

Figure 2. Cont. 

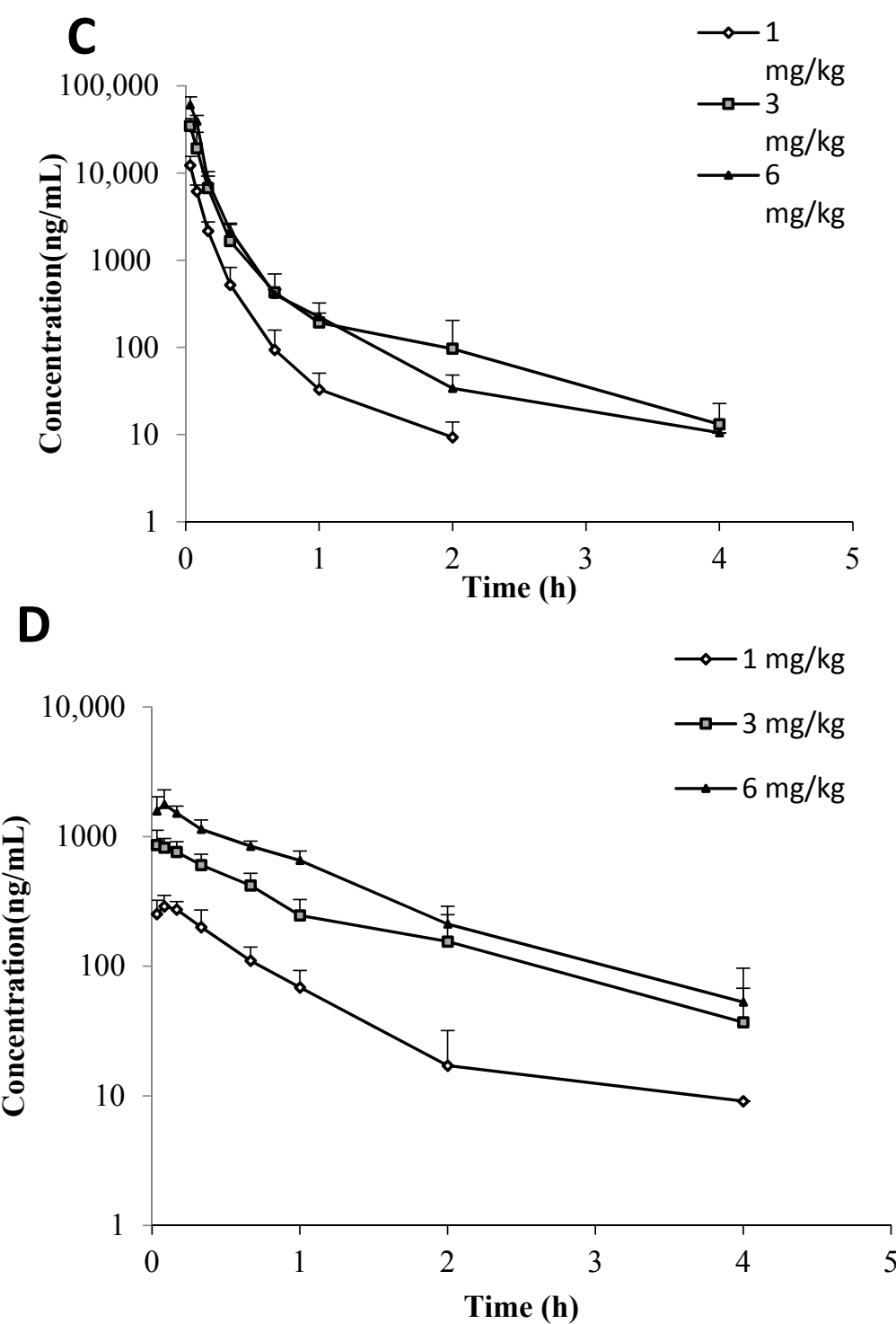

Figure 2. Plasma-concentration-versus-time profiles of C118P in rats (A), C118 in rats (B), C118P in dogs (C), and C118 in dogs (D) after i.v. injection of C118P. Doses were 5, 10, 20, and $50 \mathrm{mg} / \mathrm{kg}$ in rats and 1, $3,6 \mathrm{mg} / \mathrm{kg}$ in dogs, respectively. Data are presented as the arithmetic mean $\pm \mathrm{SD}(n=6)$. Data are not illustrated in the figure due to levels below the lower limit of quantification (LLOQ, $5 \mathrm{ng} / \mathrm{mL}$ ).

\subsection{Tissue Distribution in Rats and Tumor Bearing Mice}

The tissue concentration of C118P in rats below or slightly higher than the LLOQ (50 ng/g for tissues) at $10 \mathrm{~min}, 1 \mathrm{~h}$, and $4 \mathrm{~h}$ after intravenous administration $20 \mathrm{mg} / \mathrm{kg}$ of C118P, indicating that $\mathrm{C} 118 \mathrm{P}$ can rarely distribute to tissues. In contrast to $\mathrm{C} 118 \mathrm{P}, \mathrm{C} 118$ was widely distributed in the tissues, namely lung, kidney, heart, pancreas, ovary, spleen, thymus, muscle, liver, stomach, bone marrow, small intestine, skin, fat, testicle, and brain listed in Figure 3. The highest tissue concentration of C118 was observed in the lung (12,921 $\pm 9785 \mathrm{ng} / \mathrm{g}$ tissue weight), followed by the kidney (7639 $\pm 3407 \mathrm{ng} / \mathrm{g}$ tissue weight) and heart (6335 $\pm 4130 \mathrm{ng} / \mathrm{g}$ tissue weight) at $10 \mathrm{~min}$ after dosing. The concentration of C118 was below or slightly higher than LLOQ (50 $\mathrm{ng} / \mathrm{g}$ for tissues) at $4 \mathrm{~h}$ after dosing in most tissues. 
Table 3. Pharmacokinetic parameters of C118P and C118 in nude mice, rats and dogs after intravenous injection of C118P $(n=4$ for nude mice and $n=6$ for rats and dogs, mean $\pm \mathrm{SD}$ ).

\begin{tabular}{|c|c|c|c|c|c|c|c|c|}
\hline Species & Dose (mg/kg) & & Compound & $\mathrm{T}_{1 / 2}(\mathrm{~h})$ & $\begin{array}{c}\mathrm{C}_{2 \mathrm{~min}} \\
(\mathrm{ng} / \mathrm{mL}, \mathrm{ng} / \mathrm{g})\end{array}$ & $\begin{array}{c}\mathrm{AUC}_{0 \text {-inf }} \\
(\mathrm{ng} \times \mathrm{h} / \mathrm{mL}, \mathrm{ng} \times \mathrm{h} / \mathrm{g})\end{array}$ & $\mathrm{V}(\mathrm{mL} / \mathrm{kg}, \mathrm{g} / \mathrm{kg})$ & CL (mL/h/kg, g/h/kg) \\
\hline \multirow[t]{4}{*}{ mice } & 75 & plasma & $\mathrm{C} 118 \mathrm{P}$ & $1.96 \pm 1.07$ & $105,685.1 \pm 29,837.1$ & $13,523.8 \pm 3444.3$ & $\begin{array}{c}15,404.8 \pm \\
7499.6\end{array}$ & $5812.5 \pm 1484.3$ \\
\hline & & & C118 & $0.97 \pm 0.10$ & $42,476.2 \pm 8033.0$ & $13,371.6 \pm 1588.1$ & / & / \\
\hline & & tumor & $\mathrm{C} 118 \mathrm{P}$ & $1.16 \pm 0.76$ & $291.6 \pm 80.2$ & $217.7 \pm 9.3$ & / & / \\
\hline & & & $\mathrm{C} 118$ & $3.70 \pm 1.48$ & $13,757.4 \pm 2475.6$ & $73,027.8 \pm 24,951.2$ & / & / \\
\hline \multirow[t]{8}{*}{ rats } & 5 & plasma & $\mathrm{C} 118 \mathrm{P}$ & $0.24 \pm 0.05$ & $75,624.6 \pm 9297.9$ & $5740.3 \pm 765.5$ & $302.5 \pm 61.1$ & $882.9 \pm 116.9$ \\
\hline & & & C118 & $0.52 \pm 0.10$ & $1578.4 \pm 318.1$ & $740.7 \pm 63.2$ & / & / \\
\hline & 10 & plasma & $\mathrm{C} 118 \mathrm{P}$ & $0.21 \pm 0.05$ & $133,672.5 \pm 17,831.1$ & $10,446.7 \pm 1898.9$ & $299.4 \pm 67.6$ & $984.6 \pm 186.3$ \\
\hline & & & C118 & $0.55 \pm 0.13$ & $3720.8 \pm 973.8$ & $1598.8 \pm 192.9$ & / & / \\
\hline & 20 & plasma & $\mathrm{C} 118 \mathrm{P}$ & $0.38 \pm 0.10$ & $219,293.0 \pm 49,528.2$ & $18,743.7 \pm 3511.1$ & $582.6 \pm 114.2$ & $1108.0 \pm 272.9$ \\
\hline & & & $\mathrm{C} 118$ & $0.60 \pm 0.06$ & $7716.7 \pm 2005.6$ & $3751.1 \pm 592.5$ & / & / \\
\hline & 50 & plasma & $\mathrm{C} 118 \mathrm{P}$ & $0.80 \pm 0.57$ & $372,898.3 \pm 28,583.8$ & $38,877.1 \pm 8164.2$ & $1502.2 \pm 1065.8$ & $1338.6 \pm 324.4$ \\
\hline & & & $\mathrm{C} 118$ & $2.49 \pm 1.26$ & $20,590.0 \pm 6376.3$ & $9723.1 \pm 1298.0$ & / & / \\
\hline \multirow[t]{6}{*}{ dogs } & 1 & plasma & $\mathrm{C} 118 \mathrm{P}$ & $0.22 \pm 0.09$ & $12,260.2 \pm 3233.4$ & $1696.2 \pm 345.9$ & $181.7 \pm 51.3$ & $611.5 \pm 145.1$ \\
\hline & & & C118 & $0.49 \pm 0.18$ & $252.1 \pm 70.5$ & $214.3 \pm 79.0$ & / & / \\
\hline & 3 & plasma & $\mathrm{C} 118 \mathrm{P}$ & $0.59 \pm 0.16$ & $34,685.8 \pm 7469.8$ & $5301.0 \pm 1698.4$ & $509.2 \pm 162.0$ & $606.5 \pm 163.0$ \\
\hline & & & $\mathrm{C} 118$ & $1.05 \pm 0.27$ & $860.9 \pm 258.9$ & $910.0 \pm 294.8$ & / & / \\
\hline & 6 & plasma & $\mathrm{C} 118 \mathrm{P}$ & $0.39 \pm 0.12$ & $64,181.4 \pm 16,257.0$ & $8530.5 \pm 1549.4$ & $398.5 \pm 87.1$ & $726.1 \pm 159.0$ \\
\hline & & & $\mathrm{C} 118$ & $0.84 \pm 0.25$ & $1702.7 \pm 508.6$ & $1829.6 \pm 320.4$ & / & / \\
\hline
\end{tabular}


A

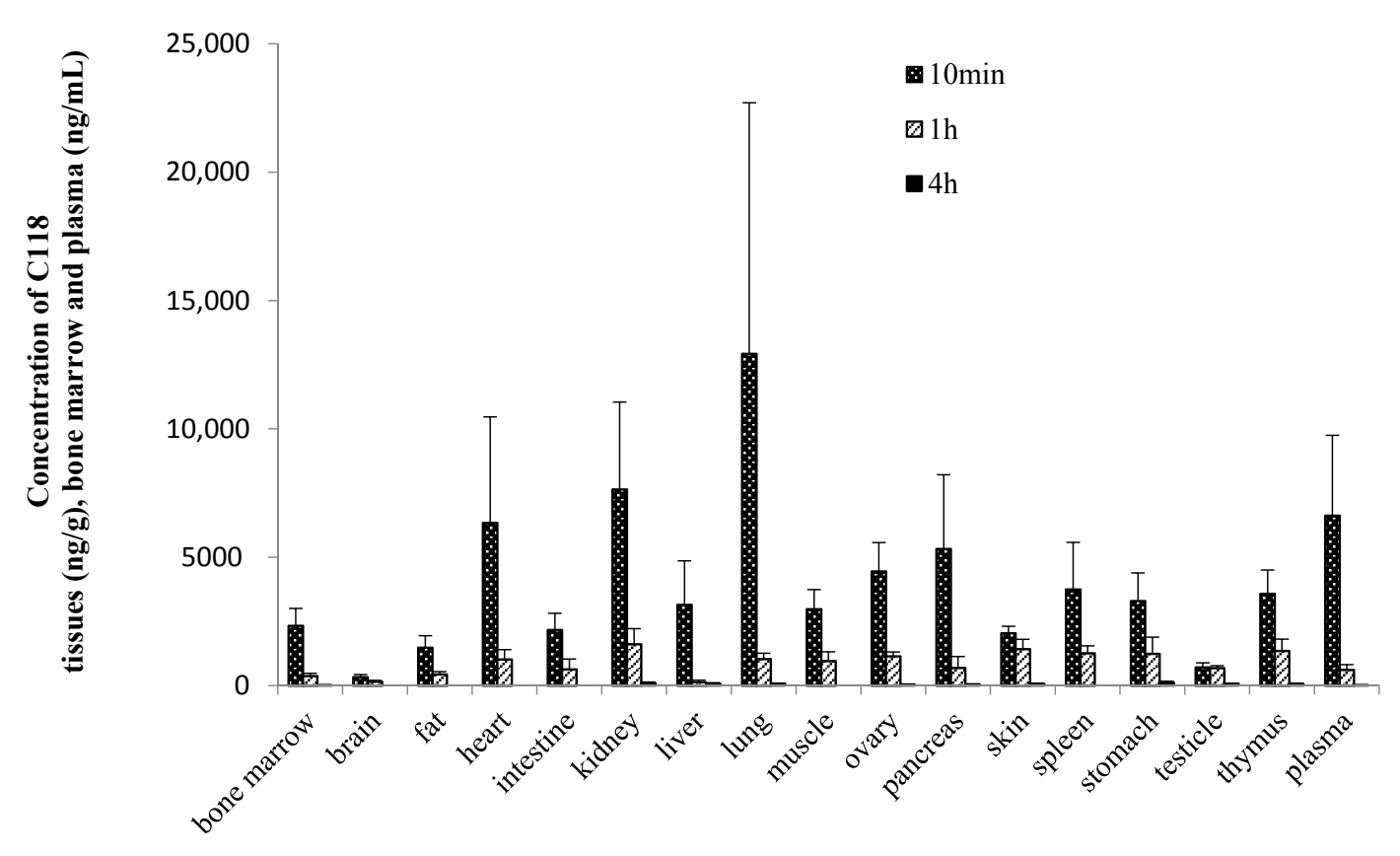

B

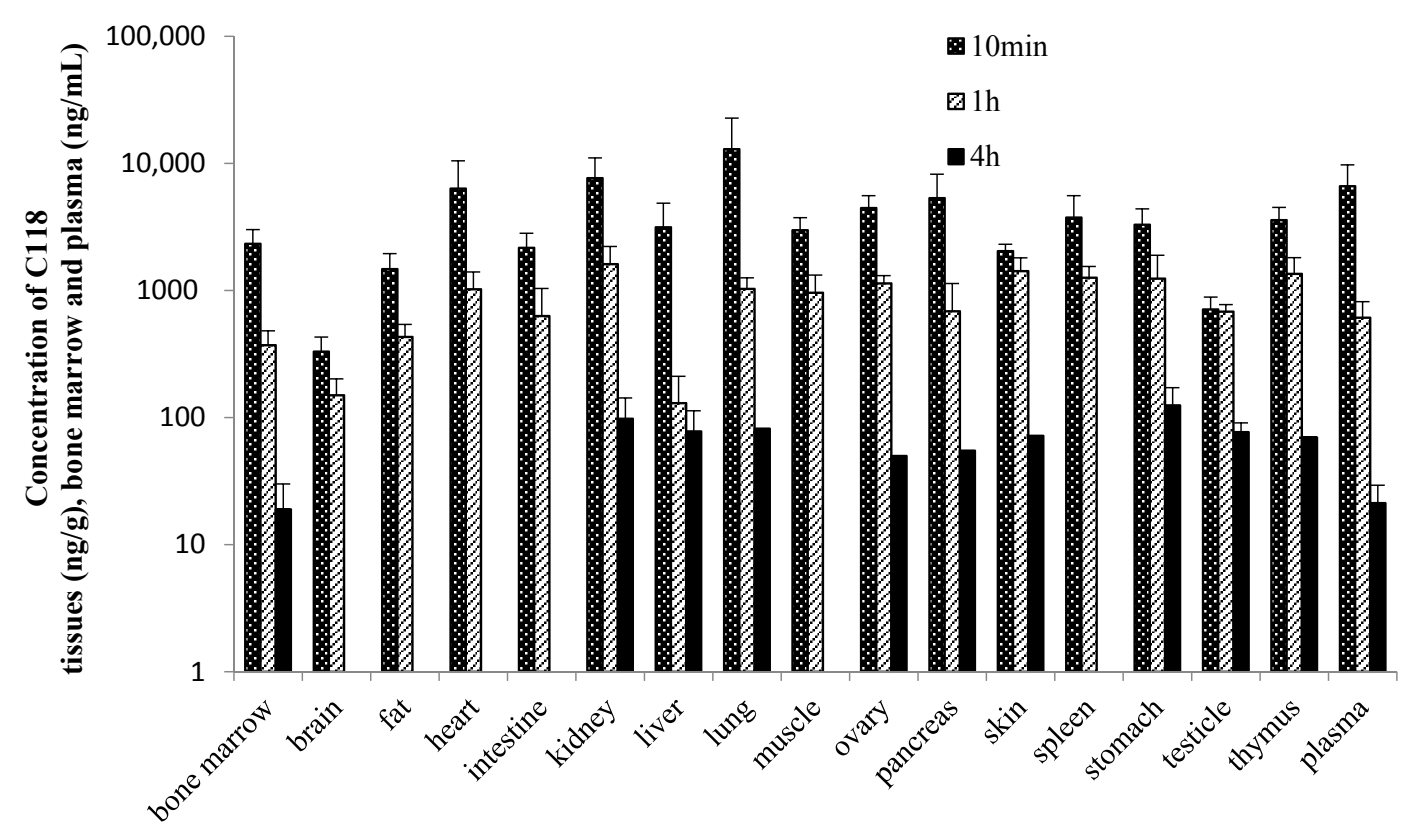

Figure 3. $\mathrm{C} 118$ concentration $(\mathrm{ng} / \mathrm{g}, \mathrm{ng} / \mathrm{mL})$ in rat tissues at $10 \mathrm{~min}, 1 \mathrm{~h}$ and $4 \mathrm{~h}$ after i.v. administration of $\mathrm{C} 118 \mathrm{P}$ at $20 \mathrm{mg} / \mathrm{kg}$. Data are presented as the arithmetic mean $\pm \mathrm{SD}(n=6)$. (A) The normal scale; (B) the semi-logarithm scale.

The distribution of $\mathrm{C} 118 \mathrm{P}$ and $\mathrm{C} 118$ in tissues of tumor bearing mice was studied and the results were showed in Table 4. Drug distribution in mice showed that C118P can hardly distribute into tissues. C118 can wildly distribute into different tissues. C118 was cleared from the tumor tissue much slower than other tissues as well as plasma. 
Table 4. The distribution of $\mathrm{C} 118 \mathrm{P}$ and $\mathrm{C} 118$ in tumor bearing mice after $i . v$. injection of $75 \mathrm{mg} / \mathrm{kg}$ of $\mathrm{C} 118 \mathrm{P}(n=4$, mean $\pm \mathrm{SD})$.

\begin{tabular}{|c|c|c|c|}
\hline Tissue & Time (h) & C118P & C118 \\
\hline \multirow{4}{*}{ Plasma } & 0.17 & $5199.4 \pm 2147.9 *$ & $26,048.0 \pm 2429.7$ \#\# \\
\hline & 1 & $191.2 \pm 60.5$ & $1730.0 \pm 986.4$ \\
\hline & 4 & $14.7 \pm 8.4$ & $132.6 \pm 56.8$ \\
\hline & 12 & $6.1 \pm 0.0$ & NF \\
\hline \multirow{4}{*}{ Tumor } & 0.17 & $115.8 \pm 24.1$ & $14,563.3 \pm 1989.9^{\#}$ \\
\hline & 1 & $73.0 \pm 15.0$ & $12,998.1 \pm 4132.3$ \\
\hline & 4 & $26.7 \pm 0.0$ & $4969.8 \pm 3414.7$ \\
\hline & 12 & NF & $1327.7 \pm 1124.0$ \\
\hline \multirow{4}{*}{ Brain } & 0.17 & NF & $3562.8 \pm 796.6 \#$ \\
\hline & 1 & NF & $1250.7 \pm 351.3$ \\
\hline & 4 & NF & $109.1 \pm 22.0$ \\
\hline & 12 & NF & NF \\
\hline \multirow{4}{*}{ Lung } & 0.17 & $130.2 \pm 7.5$ & $26,923.2 \pm 4389.0 \#$ \\
\hline & 1 & NF & $1852.3 \pm 929.3$ \\
\hline & 4 & NF & $231.3 \pm 181.7$ \\
\hline & 12 & NF & $\mathrm{NF}$ \\
\hline \multirow{4}{*}{ Ovary } & 0.17 & NF & $26,723.8 \pm 18,229.6$ \\
\hline & 1 & NF & $3308.6 \pm 2611.1$ \\
\hline & 4 & NF & NF \\
\hline & 12 & NF & NF \\
\hline \multirow{4}{*}{ Muscle } & 0.17 & $355.4 \pm 64.1$ & $15,202.5 \pm 8814.7$ \\
\hline & 1 & NF & $946.8 \pm 390.6$ \\
\hline & 4 & NF & $136.4 \pm 2.8$ \\
\hline & 12 & NF & NF \\
\hline
\end{tabular}

NF: not found, ${ }^{*}:$ compared with data from CA4P $(p<0.05)$ in supplemental data (Table S2); ${ }^{\#}$ compared with data from CA4 $(p<0.05)$ in supplemental data (Table S2); ${ }^{\#}$ : compared with data from CA4 $(p<0.01)$ in supplemental data (Table S2).

\subsection{Excretion in Rats}

The cumulative molar excretion percentages of C118P and C118 in bile, urine, and feces of rats after intravenous administration of C118P at $20 \mathrm{mg} / \mathrm{kg}$ (Figure 4 ) are $0.123 \pm 0.044 \%, 1.06 \pm 0.55 \%$, and $12.98 \pm 4.33 \%$, respectively. Further metabolite identification results suggest that the majority of the drugs were excreted in the form of glucuronic acid conjugate and sulfuric acid conjugate, which account for the $42.3 \pm 7.3 \%$ and $8.8 \pm 4.8 \%$ excretion of dose in bile, respectively. Glucuronic acid conjugation in urine accounted for the $8.0 \pm 2.0 \%$ excretion of the dose in $72 \mathrm{~h}$, and no sulfuric acid conjugation was found in urine.

Metabolic stability study showed that C118P is quite stable in liver microsomes from mice, rats, monkeys, and humans. C118 can be metabolized in liver microsomes from different species, with similar ratio of human, mice and SD rats, and very rapid in monkey and very slow in dog. $O$-demethyl, hydroxylated, in the benzyl ring and $N$-oxylation and $N$-acetylation were found. Further glucuronization and sulfation were also observed in the bile excretion. 

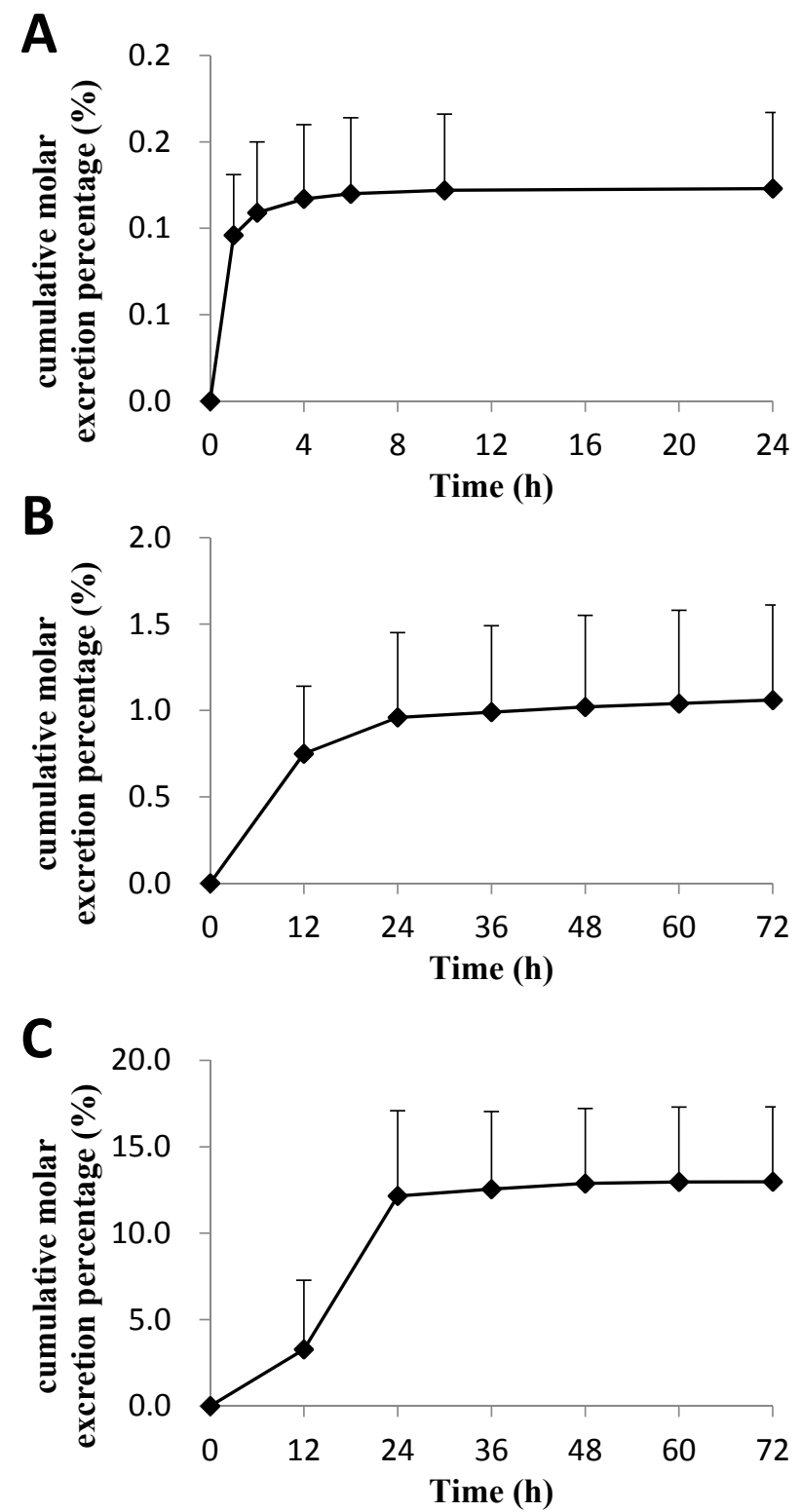

Figure 4. The cumulative molar excretion percentages of $\mathrm{C} 118 \mathrm{P}$ and $\mathrm{C} 118$ in bile $(\mathbf{A}, n=10)$, urine $(\mathbf{B}, n=6)$ and feces $(\mathbf{C}, n=6)$ of rats after i.v. administration of $\mathrm{C} 118 \mathrm{P}$ at $20 \mathrm{mg} / \mathrm{kg}$. Data are presented as the arithmetic mean $\pm \mathrm{SD}$.

\subsection{Discussion}

In our preclinical pharmacokinetic study, C118P can be quickly hydrolyzed into C118 after an intravenous administration, and C118 can enter the tissues instantly. The highest tissue concentration of C118 was observed at $10 \mathrm{~min}$ after injection. The unbound C118 in plasma is slightly higher than C118P. C118P can hardly penetrate the tissue, while C118 could distribute wildly into tissues. Drug distribution in mice showed that $\mathrm{C} 118$ was cleared from the tumor tissue much slower than other tissues, which might be a benefit for antitumor drugs.

We conducted a phase-I and -II metabolic stability assay to predict the in vivo metabolism of $\mathrm{C} 118 \mathrm{P}$ and $\mathrm{C} 118$. The metabolic clearances, $\mathrm{T}_{1 / 2}$ of $\mathrm{C} 118 \mathrm{P}$, were not calculated because most of the drug remained metabolically intact over $2 \mathrm{~h}$ in the live microsome incubation system. The transformation of C118P to C118 is mainly carried out in the blood stream. The rate of biotransformation of C118P to $\mathrm{C} 118$ is quite difficult to acquire. The in vitro incubation results showed that $\mathrm{C} 118 \mathrm{P}$ is quite stable in mice, rat, monkey, and human microsome incubation systems but not stable in the dog microsome 
incubation system. The stability study showed that C118 can be rapidly metabolized in the monkey liver microsome incubation system, with a half-life of $2.2 \mathrm{~min}$. C118 is metabolized at the similar speed in mice, rat, and human, with the half-life of 15.5, 10.3, and 11.9 min, respectively. C118 is relatively stable in the dog liver microsome incubation system, with a half-life of $70.1 \mathrm{~min}$. In vivo pharmacokinetic study showed that the mouse plasma half-life $\left(t_{1 / 2}\right)$ is longer for C118P than C118. All other animal half-lives show that the half-life $\left(t_{1 / 2}\right)$ is shorter for C118P than C118. The (AUC 0 -inf) and $\mathrm{C}_{30 \mathrm{~s}}$ of $\mathrm{C} 118 \mathrm{P}$ at $50 \mathrm{mg} / \mathrm{kg}$ in rats and $6 \mathrm{mg} / \mathrm{kg}$ in dogs, and the $\mathrm{C}_{2 \mathrm{~min}}$ of $\mathrm{C} 118$ at $6 \mathrm{mg} / \mathrm{kg}$ in dogs increased less than the dosage increase, suggesting nonlinear pharmacokinetics occurred at high dose. Caution should be paid during the dose scaling during clinical trials, especially at high dose.

When mice were treated with the same dose of C118P or CA4P, the concentration of C118 in plasma, tumor, lung, and muscle is higher than that of CA4 (Table S2). The plasma concentration of $\mathrm{C} 118 \mathrm{P}$ is lower than that of CA4P, which suggests that the transformation of C118P into C118 is quicker than CA4P. The concentration of C118 in brain and ovary is lower than that of CA4. Further comparison studies should be carried out in clinical research.

\section{Materials and Methods}

\subsection{Chemicals and Reagents}

C118P standard compound (C118 phosphate, chemical purity is $97.3 \%$ ), C118P injection (C118P content is $95.6 \%$ ) and C118 (chemical purity is $95.9 \%$ ) were manufactured by Nanjing Sanhome Pharmaceutical Co. Ltd. (Nanjing, China). Colchicine (chemical purity is $98.8 \%$, as an internal standard) was purchased from Meryer (Shanghai) Chemical Technology Co., Ltd (Shanghai, China). Methanol and acetonitrile were purchased from Merck (HPLC gradient grade, LiChrosolv GG, Darmstadt, Germany). Milli-Q water was generated from Milli-Q system (Gradient A1, Millipore Inc, Bedford, MA, USA). Pooled human liver microsomes (HLMs) were prepared from eleven Mongolian donors aged from 24 to 38 and were purchased from RILD Research Institute for Liver Diseases Co. Ltd. (Shanghai, China). HPLC grade or the best grade commercially available was used in our study for all other chemicals.

\subsection{C118P and C118 Analysis in Biological Samples}

The concentrations of C118P and C118 in biological samples were determined by HPLC coupled with tandem mass spectrometric detection (LC-MS/MS) after protein precipitation.

The bioanalytical method for simultaneous quantification of C118P and C118 in different matrix was fully validated. Briefly, the plasma, tissue homogenate, thigh bone soak solution, bile, urine, and feces suspension samples were prepared by precipitation with methanol containing internal standard $(10 \mathrm{ng} / \mathrm{mL})$. One milliliter of methanol containing internal standard $(10 \mathrm{ng} / \mathrm{mL})$ was added to $50 \mu \mathrm{L}$ of biofluid samples ( $100 \mu \mathrm{L}$ for feces suspensions). The mixture was vortexed for $3 \mathrm{~min}$ and centrifuged at 18,000 rpm for $5 \mathrm{~min}$. The supernatant was removed and centrifuged again under the same condition. A volume of $200 \mu \mathrm{L}$ of the second supernatant was transferred into a vial and $5 \mu \mathrm{L}$ of which was injected into the HPLC-MS/MS system for analysis.

A Shimadzu LC-20A system was equipped with a degasser, binary pump, autosampler, and thermostat-controlled column compartment. Chromatographic separation was performed on an Eclipse XDB-C18 column $(4.6 \times 150 \mathrm{~mm}, 5 \mu \mathrm{m}$, Agilent) (Santa Clara, CA, USA). Mobile phase was consisted with a mixture of acetonitrile (B)- $0.4 \%$ formic acid (A) at a flow rate of $0.7 \mathrm{~mL} / \mathrm{min}$. The time program of the gradient is described in Table 5. The column temperature was maintained at $40{ }^{\circ} \mathrm{C}$. AB Sciex API 4000 triple quadrupole mass spectrometer (Sciex, Framingham, MA, USA) equipped with an electro-spray-ionization (ESI) Source was used for mass spectrometric detection. The mass spectrometer was operated in the positive mode. The following MS/MS parameters were used: Curtain Gas, 30 Arb; Collision Gas, 10 Pa; Ion Source Gas1, 70 Arb; Ion Source Gas2, 70 Arb; IonSpray Voltage, 5500V; Ion Spray Temperature, $600{ }^{\circ} \mathrm{C}$. Multiple reaction monitoring (MRM) mode 
was used for mass detection. The optimized MRM fragmentation transitions for C118P was $m / z$ $407.1 \rightarrow m / z 327.1$ with a declustering potential of $120 \mathrm{~V}$ and Collision Energy of $35 \mathrm{eV}$ and for C118 was $m / z 327.1 \rightarrow m / z 312.2$ with a declustering potential of $140 \mathrm{~V}$ and collision energy of $36 \mathrm{eV}$. For colchicines (IS), the optimized MRM fragmentation transition was $m / z 400.1 \rightarrow m / z 326.1$ with a declustering potential of $104 \mathrm{~V}$ and collision energy of $36 \mathrm{Ev}$ (Figure S2). The linear range of this analytical method was 5-2000 ng/mL for C118P and 5-500 ng/mL for C118.

Table 5. Gradient program for HPLC separation of C118P and C118.

\begin{tabular}{ccc}
\hline \multirow{2}{*}{ Time (min) } & \multicolumn{2}{c}{ Mobile Phase } \\
\cline { 2 - 3 } & A (\%) & B (\%) \\
\hline 0 & 95 & 5 \\
1 & 95 & 5 \\
5.5 & 40 & 60 \\
7 & 2 & 98 \\
7.5 & 2 & 98 \\
7.51 & 95 & 5 \\
12 & 95 & 5
\end{tabular}

Solvent A: $0.4 \%$ formic acid. Solvent B: acetonitrile.

\subsection{Plasma Protein Binding}

Plasma protein binding of $\mathrm{C} 118 \mathrm{P}$ and $\mathrm{C} 118$ were determined by ultrafiltration at four concentrations (C118P: 400, 4000, 40,000, and 400,000 ng/mL, C118: 20, 200, 2000, and 20,000 ng/mL) in pooled plasma from Sprague-Dawley rats, beagle dogs, and humans. Stock solutions of C118P and C118 dissolved in methanol were diluted with blank plasma to achieve the test concentrations (the methanol volume is less than $10 \%$ of the plasma). The plasma was incubated for $1 \mathrm{~h}$ in a water bath at $37^{\circ} \mathrm{C}$. The total concentration of C118P and C118 of spiked plasma (TC) was analyzed by previously described methods. Ultrafiltration was performed with activated high speed centrifugal tubes (Millipore, Burlington, MA, USA). Plasma samples $(0.4 \mathrm{~mL})$ were added to the upper layer of the high speed centrifugal tubes, and then centrifuged at $12,000 \mathrm{~g}$ for $10 \mathrm{~min}$. The concentration of unbound C118P and C118 in filtrate (PF) was similarly determined by the previously described methods. The percentage of free fraction $(\mathrm{fu})$ of $\mathrm{C} 118 \mathrm{P}$ and C118 was calculated as follows: $\mathrm{fu}=(\mathrm{PF} / \mathrm{TC}) \times 100 \%$.

\subsection{Blood Plasma Ratio}

The ratio of C118P and C118 in blood and plasma was studied. The whole blood was obtained from healthy volunteer and was separated into two parts to obtain whole blood and plasma. Standard solution was added into whole blood and plasma to mimic the incurred sample. After incubation for $30 \mathrm{~min}$, the whole blood was separated into two parts. One was frozen and thawed to obtain the homogenous whole blood and the other sample was centrifuged to obtain plasma. The samples were analyzed by the established LC-MS/MS method and the blood plasma ratio was calculated.

\subsection{Metabolic Stability in Liver Microsomes}

The in vitro metabolic stability of C118P and C118 were estimated in mice, rat, dog, monkey, and human liver microsomes (Research Institute for Liver Diseases Co. Ltd (Shanghai, China)). The incubation mixture contains C118P or C118, NADP (1.0 mM), G-6-P (10 mM), PDH (2 units/mL), $\mathrm{MgCl}_{2}(10 \mathrm{mM})$, and liver microsomes (mice, rats, dogs, monkeys, or humans, $1.0 \mathrm{mg}$ protein $/ \mathrm{mL}$ ) in phosphate buffer. A total of $200 \mu \mathrm{L}$ of the mixture was removed and quenched with $600 \mu \mathrm{L}$ acetonitrile in an ice bath at $0,15,30,60,120$, and 240 min after the addition of NADPH.

$\mathrm{CL}_{\text {int, in vitro }}$ (the in vitro intrinsic clearance, Equation (1)) was calculated from the $\mathrm{t}_{1 / 2}$ of C118 disappearance, where $C_{\text {protein }}$ is the protein concentration during the incubation, and $t_{1 / 2}$ was 
determined by the slope $(\mathrm{k})$ of the log-linear regression analysis of the concentration versus time profiles; thus, $t_{1 / 2}=\ln 2 / k$. The in vivo clearance values (Equation (2)) of mice, rat, dog, monkey,

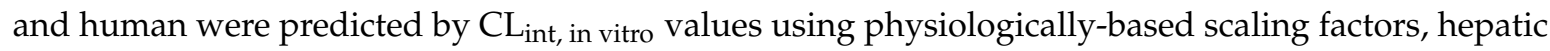
microsomal protein concentrations (47, 47, 58, 32, and $32 \mathrm{mg}$ protein/g liver) [13], and liver weights (54.9, 36.6, 32.9, 24.8 and $25.7 \mathrm{~g} / \mathrm{kg}$ body weight) [13]. The in vivo hepatic clearance ( $\mathrm{CL}_{\mathrm{H}}$, Equation (3)) was then calculated by using $C L_{\text {int }}$ and hepatic blood flow, $\mathrm{Q}\left(127,70,40,44\right.$, and $20 \mathrm{~mL} \cdot \mathrm{min}^{-1} \cdot \mathrm{kg}^{-1}$ in rats, dogs, monkey, and humans, respectively) [14-16], in the well-stirred liver model disregarding all binding [17]. The hepatic extraction ratio was calculated as $C L_{H}$ divided by $\mathrm{Q}$.

$$
\begin{gathered}
C L_{\text {int, in vitro }}=\left(0.693 / \mathrm{t}_{1 / 2}\right) \times\left(1 / \mathrm{C}_{\text {protein }}\right) \\
\mathrm{CL}_{\text {int }}=\mathrm{CL}_{\text {int }, \text { in vitro }} \times(\mathrm{mg} \text { protein } / \mathrm{g} \text { liver weight }) \times(\text { gliver weight } / \mathrm{kg} \text { body weight }) \\
\mathrm{CL}_{\mathrm{H}}=\left(\mathrm{Q} \times \mathrm{CL}_{\text {int }}\right) /\left(\mathrm{Q}+\mathrm{CL}_{\text {int }}\right)
\end{gathered}
$$

\subsection{PK in Mice, Rats, and Dogs}

Experiments in relate to animals were conducted in accordance with the guidelines of Animal Use and Care of the National Institutes of Health and approved by the China Pharmaceutical University Animal Use and Care Committee.

The nude mice (BALB/cA) implanted with NCI-H460 tumor were provided by Shanghai Institute of Materia Medica. A total of 36 mice were divided into 9 groups with four animals in each group. After fasting overnight with free access to water, the mice were treated with $75 \mathrm{mg} / \mathrm{kg} \mathrm{C} 118 \mathrm{P}$ by i.v. The blood samples were collected at 2, 10, 20, $40 \mathrm{~min}, 1,2,4,8,12 \mathrm{~h}$ after treatment and the mice were anaesthetized and decapitated to obtain the blood and tumor tissue. Blood, brain, muscle, ovary, and lung from mice in the PK study were collected at $10 \mathrm{~min}, 1,4$, and $12 \mathrm{~h}$. Tissues were cleaned by absorbent filter paper to remove the blood. Bloods were centrifuged at $10,000 \times g$ for $5 \mathrm{~min}$. Each tissue $(0.2 \mathrm{~g})$ was homogenized with $2 \mathrm{~mL}$ water. The plasma samples and the homogenates were then processed and determined by the method described above. The concentration was determined by the calibration curve and the actual concentration was corrected by multiplying by 10 according to the dilution times.

The SD rats were supplied by the medical animal experiment center of Chinese People's Liberation Army Nanjing military region. Twenty-four rats (210-300 g) with half males and half females were divided randomly into four groups. $\mathrm{C} 118 \mathrm{P}$ was dissolved in saline to achieve different concentrations for intravenous administration. After fasting overnight, the rats were administered with a single intravenous dose of 5, 10, 20, or $50 \mathrm{mg} / \mathrm{kg}$ C118P. Blood samples (approximately $200 \mu \mathrm{L}$ ) were collected in EDTA-coated tubes pre-dose (0), and 30s, 2, 5, 10, 20, $40 \mathrm{~min}, 1,2,4,8,12$ and $24 \mathrm{~h}$ post dose. Plasma was prepared by centrifugation at $8000 \mathrm{rpm}$ for $5 \mathrm{~min}$, and the plasma samples were then prepared and determined by the method described above.

The beagle dogs were purchased from Nanjing Ya Dong experimental animal research center. Twelve beagle dogs with half males and half females were divided randomly into two groups. $\mathrm{C} 118 \mathrm{P}$ was dissolved in saline to different concentrations for intravenous administration. After fasting overnight with free access to water, the dogs were administered a single intravenous dose of 1 or $3 \mathrm{mg} / \mathrm{kg} \mathrm{C118P.} \mathrm{After} \mathrm{a} \mathrm{one-week} \mathrm{wash-out} \mathrm{period,} \mathrm{the} \mathrm{group} \mathrm{of} 1 \mathrm{mg} / \mathrm{kg}$ were administered another single intravenous dose of $6 \mathrm{mg} / \mathrm{kg} \mathrm{C118P}$. Blood samples (approximately $1 \mathrm{~mL}$ ) were collected in EDTA-coated tubes at times of 0, 2, 5, 10, 20, $40 \mathrm{~min}, 1,2,4,8,12$ and $24 \mathrm{~h}$. Plasma was prepared by centrifugation at $8000 \mathrm{rpm}$ for $5 \mathrm{~min}$, and the plasma samples were then prepared and determined by the method described above.

The area under the plasma-concentration-versus-time curve from 0 to infinite $\left(\mathrm{AUC}_{0 \text {-inf }}\right)$, the elimination half-life $\left(t_{1 / 2}\right)$, the systemic plasma clearance $(C L)$ and the volume of distribution $(V)$ were calculated by non-compartmental analysis with WinNonlin software v6.3 (Pharsight Corporation, St. Louis, MO 63144, USA) from the plasma concentration data of C118P and C118, respectively. 
The instantaneous concentrations after intravenous to rats $\left(C_{30 s}\right)$ or dogs $\left(C_{2 \min }\right)$ were obtained directly from the observed data.

Due to the rapid transformation of $\mathrm{C} 118 \mathrm{P}$ into $\mathrm{C} 118$, there is no direct way to calculate the rate of transformation, thus a two-compartment model with metabolism involved was developed (Figure S3). The transformation rate from $\mathrm{C} 118 \mathrm{P}$ into $\mathrm{C} 118$ was simulated by fitting the two-serial data of prodrug $\mathrm{C} 118 \mathrm{P}$ and $\mathrm{C} 118$ in rats and dogs.

\subsection{Tissue Distribution in Rats}

Eighteen rats (weight 220-260 g) with half males and half females were randomly assigned to there groups to carry out a tissue distribution study and fasted overnight. Blood and tissue samples, including the brain, skin, muscle, fat, testicle/ovary, pancreas, spleen, kidney, stomach, small intestine, heart, liver, lung, thymus, and thighbone were collected at $10 \mathrm{~min}, 1$, and $4 \mathrm{~h}$ after intravenous administration $(20 \mathrm{mg} / \mathrm{kg})$. Blood was centrifuged for plasma samples. Tissue samples were rinsed with water to remove the blood and blotted dry with filter paper. An accurately-weighed amount of the tissue sample $(0.2 \mathrm{~g})$ or the entire organ for which weight less than $0.2 \mathrm{~g}$ was individually homogenized with EDTA solution $(40 \mathrm{mg} / \mathrm{mL}, 2.0 \mathrm{~mL})$. The left thigh bone was crushed and then soaked overnight in methanol-EDTA solution $(1: 1, v / v)$. A volume of $50 \mu \mathrm{L}$ of homogenate or soak solution was prepared by protein precipitation and determined by the method described above. Tissue weights were used for calculating the concentrations (ng/g) of C118P and C118 in tissues.

\subsection{Excretion in Rats}

Twelve rats (weight 220-260 g) with half males and half females were anesthetized with diethyl ether after fasted overnight. A median laparotomy was performed and the bile duct was cannulated with a catheter. After intravenous administration $(20 \mathrm{mg} / \mathrm{kg})$ of C118P solution, bile samples were collected at 1, 2, 4, 6, 10 and $24 \mathrm{~h}$ in EDTA-coated tubes. The accurate volume of bile samples were measured by weight loss method. A volume of $50 \mu \mathrm{L}$ of bile was prepared by protein precipitation and determined by the method described above. The total cumulative molar excretion percentage of $\mathrm{C} 118 \mathrm{P}$ and $\mathrm{C} 118$ in bile of ten rats was calculated according to the total molar amount of C118P and C118 and the dose.

Six rats (weight 200-230 g) with half males and half females were fasted overnight. After intravenous administration $(20 \mathrm{mg} / \mathrm{kg})$, urine and feces samples were collected at $12,24,36,48$, 60 and $72 \mathrm{~h}$. The feces were collected in $200 \mathrm{~mL}$ of EDTA solution $(100 \mathrm{mg} / \mathrm{mL})$ and grinded into a suspension. The accurately volume amount of urine and feces samples were measured by weight loss method. A volume of $50 \mu \mathrm{L}$ of urine or feces suspension was prepared by protein precipitation and determined by the method described above. The cumulative molar excretion percentage of $\mathrm{C} 118 \mathrm{P}$ and C118 in urine or feces was calculated according to the concentrations of C118P and C118, the volume of each time period.

\section{Conclusions}

In summary, we studied the pharmacokinetic profile of $\mathrm{C} 118 \mathrm{P}$, the prodrug of $\mathrm{C} 118$, a novel microtubule protein inhibitor, which is now under clinical trial in China. After i.v., C118P could be hydrolyzed into C118 rapidly, with C118P and C118 detectable in the blood simultaneously. C118 could widely distribute into tissues, with C118P mainly staying in the bloodstream. In tumor-bearing nude mice, the concentration of $\mathrm{C} 118$ is high in lung, ovary, and tumor, with an extended half-life in tumors. Since C118 is the active moiety, the PK profile is focused on C118 based on the preclinical study data and its chemistry property. No human pharmacokinetic data could be obtained at the present stage, and the first in-human dosage prediction based on preclinical data could help the phase I clinical trial design and reduce the toxicity risk in humans. 
Supplementary Materials: The following are available online, Figure S1: (A) Concentration-time curves of C118P after $\mathrm{C} 118 \mathrm{P}$ incubation with mice, rat, dog, monkey and human liver microsomes $(\mathrm{ng} / \mathrm{mL})$; (B) Concentration-time curves of $\mathrm{C} 118$ after $\mathrm{C} 118 \mathrm{P}$ incubation with mice, rat, dog, monkey and human liver microsomes $(\mathrm{ng} / \mathrm{mL})$; Figure S2: The mass spectrum of C118P (A), C118 (B) and internal standard colchicines (C); Figure S3: The pharmacokinetic model of C118P and C118 in rat after i.v. C118P; Figure S4: The simulation of PK profile at $20 \mathrm{mg} / \mathrm{kg}$ in rat $(\mathrm{A})$ and $6 \mathrm{mg} / \mathrm{kg}$ (B) in dog based on initial parameters calculated by Winnonlin; Table S1: The initial parameters and simulated parameters of $\mathrm{C} 118 \mathrm{P}$ and $\mathrm{C} 118$ used in the tandem two-compartmental model; Table S2: The distribution of CA4P and CA4 in tumor bearing mice after i.v. injection of $75 \mathrm{mg} / \mathrm{kg}$ of CA4P.

Author Contributions: C.Z., J.S., and X.Z. (Xiaolan Zhang) carried out the study design, data analysis, and paper writing. G.W. and B.Y. designed the research. Y.P., X.Z. (Xiaolan Zhang), X.Z. (Xueyuan Zhang), and H.W. performed the experiment.

Funding: This work was supported by the Jiangsu Province Key Laboratory of Drug Metabolism and Pharmacokinetics Projects (BM2012012) and the National Key New Drug Creation Special Programs (Nos. 2011ZX09401-003 and 2017ZX09101001).

Acknowledgments: We thank Zhengyu Cao and Xiaoxin Qi for reviewing of the manuscript and the help of modeling by SAAM II from Prof Rodney Ho (University of Washington) are highly appreciated.

Conflicts of Interest: The authors declare no conflict of interest. The founding sponsors had no role in the design of the study; in the collection, analyses, or interpretation of data; in the writing of the manuscript, and in the decision to publish the results.

\section{References}

1. Chen, W.Q.; Zheng, S.R.; Baade, P.D.; Zhang, S.W.; Zeng, H.M.; Bray, F.; Jemal, A.; Yu, X.Q.; He, J. Cancer statistics in China, 2015. CA Cancer J. Clin. 2016, 66, 115-132. [CrossRef] [PubMed]

2. Folkman, J. Tumor angiogenesis: Therapeutic implications. N. Engl. J. Med. 1971, 285, 1182-1186. [PubMed]

3. Weidner, N.; Folkman, J.; Pozza, F.; Bevilacqua, P.; Allred, E.N.; Moore, D.H.; Meli, S.; Gasparini, G. Tumor angiogenesis-A new significant and independent prognostic indicator in early-stage breast-carcinoma. J. Natl. Cancer I 1992, 84, 1875-1887. [CrossRef]

4. Weidner, N.; Carroll, P.R.; Flax, J.; Blumenfeld, W.; Folkman, J. Tumor angiogenesis correlates with metastasis in invasive prostate carcinoma. Am. J. Pathol. 1993, 143, 401-409. [PubMed]

5. Folkman, J. Angiogenesis inhibitors generated by tumors. Mol. Med. 1995, 1, 120-122. [CrossRef] [PubMed]

6. Pluda, J.M. Tumor-associated angiogenesis: Mechanisms, clinical implications, and therapeutic strategies. Semin. Oncol. 1997, 24, 203-218. [PubMed]

7. Malonne, H.; Langer, I.; Kiss, R.; Atassi, G. Mechanisms of tumor angiogenesis and therapeutic implications: Angiogenesis inhibitors. Clin. Exp. Metastas 1999, 17, 1-14. [CrossRef]

8. Banerjee, S.; Hwang, D.J.; Li, W.; Miller, D.D. Current advances of tubulin inhibitors in nanoparticle drug delivery and vascular disruption/angiogenesis. Molecules 2016, 21, 1468. [CrossRef] [PubMed]

9. Zhang, C.; Zhong, B.; Yang, S.M.; Pan, L.K.; Yu, S.W.; Li, Z.J.; Li, S.C.; Su, B.; Meng, X.B. Synthesis and biological evaluation of thiabendazole derivatives as anti-angiogenesis and vascular disrupting agents. Bioorgan Med. Chem. 2015, 23, 3774-3780. [CrossRef] [PubMed]

10. Bates, D.; Eastman, A. Microtubule destabilising agents: Far more than just antimitotic anticancer drugs. Br. J. Clin. Pharmacol. 2017, 83, 255-268. [CrossRef] [PubMed]

11. Remick, S.C.; Dowlati, A.; Robertson, K.; Spiro, T.; Connell, C.; Levitan, N.; Stratford, M. Phase I pharmacokinetic study of single dose intravenous (iv) combretastatin a4 prodrug (ca4p) in patients (pts) with advanced cancer. Clin. Cancer Res. 1999, 5, 3732.

12. He, X.X.; Li, S.; Huang, H.; Li, Z.M.; Chen, L.K.; Ye, S.; Huang, J.J.; Zhan, J.; Lin, T.Y. A pharmacokinetic and safety study of single dose intravenous combretastatin a4 phosphate in chinese patients with refractory solid tumours. Br. J. Clin. Pharmacol. 2011, 71, 860-870. [CrossRef] [PubMed]

13. Ring, B.J.; Chien, J.Y.; Adkison, K.K.; Jones, H.M.; Rowland, M.; Do Jones, R.; Yates, J.W.T.; Ku, M.S.; Gibson, C.R.; He, H.D.; et al. Phrma cpcdc initiative on predictive models of human pharmacokinetics, Part 3: Comparative assessement of prediction methods of human clearance. J. Pharm. Sci. 2011, 100, 4090-4110. [CrossRef] [PubMed]

14. Hosea, N.A.; Collard, W.T.; Cole, S.; Maurer, T.S.; Fang, R.X.; Jones, H.; Kakar, S.M.; Nakai, Y.; Smith, B.J.; Webster, R.; et al. Prediction of human pharmacokinetics from preclinical information: Comparative accuracy of quantitative prediction approaches. J. Clin. Pharmacol. 2009, 49, 513-533. [CrossRef] [PubMed] 
15. Boxenbaum, H. Interspecies variation in liver weight, hepatic blood flow, and antipyrine intrinsic clearance: Extrapolation of data to benzodiazepines and phenytoin. J. Pharmacokinet Biopharm. 1980, 8, 165-176. [CrossRef] [PubMed]

16. Ito, K.; Houston, J.B. Prediction of human drug clearance from in vitro and preclinical data using physiologically based and empirical approaches. Pharm. Res. 2005, 22, 103-112. [CrossRef] [PubMed]

17. De Buck, S.S.; Sinha, V.K.; Fenu, L.A.; Gilissen, R.A.; Mackie, C.E.; Nijsen, M.J. The prediction of drug metabolism, tissue distribution, and bioavailability of 50 structurally diverse compounds in rat using mechanism-based absorption, distribution, and metabolism prediction tools. Drug Metab. Dispos. 2007, 35, 649-659. [CrossRef] [PubMed]

Sample Availability: Samples of the compounds C118P and C118 are available from the authors.

(C) 2018 by the authors. Licensee MDPI, Basel, Switzerland. This article is an open access article distributed under the terms and conditions of the Creative Commons Attribution (CC BY) license (http:/ / creativecommons.org/licenses/by/4.0/). 